Acta vet. scand. $1964,5,123-132$.

From the Royal Veterinary and Agricultural College, Department of Obstetrics and Gynaecology, Copenhagen.

\title{
RENAL SODIUM AND POTASSIUM EXCRETION IN DISEASED CATTLE ESTIMATED WITHOUT MEASUREMENT OF THE URINE VOLUME*)
}

By

\author{
J. M. Skydsgaard
}

Is is important to know the renal excretion of sodium and potassium in patients with water- and electrolyte deficiencies, because continual renal loss of electrolytes must be considered in diagnosis and therapy. It is, however, difficult to obtain a sufficiently exact measurement of the urine volume with urine collection devices or permanent bladder catheter in bovine patients. In addition to this the electrolyte excretion may be disturbed by the measurement of the urine volume (Knudsen, 7) presumably by neuro-hormonal influences on kidney function. De Groot \& Aafjes (5) have indicated a possibility of avoiding the measurement of the urine volume. In normal cattle these authors showed a renal excretion of creatinine of such a constancy that the creatinine concentration was an expression of the magnitude of urine volume per unit of time. Therefore, in normal cattle it should be possible to substitute urine creatinine concentration for the measurement of urine volume. The principle has been applied in the estimation of the magnesium excretion in cases of hypomagnesaemia in cattle (Kemp et al. 6).

Poulsen (9) showed that the renal creatinine excretion in cattle almost exclusively takes place by glomerular filtration. It is thus uncertain whether the principle mentioned can be applied in cases of water- and electrolyte disturbances, in which

*) This investigation has been supported by Statens almindelige Videnskabsfond. 
the glomerular filtration rate is influenced to a variable extent. The present investigation has been carried out in order to study this problem.

\section{MATERIAL AND METHODS}

Ten obstetrical bovine patients were examined, five of which showed severe disturbances in the fluid- and electrolyte balances. The renal sodium and potassium excretions were determined by both the conventional method (equation 1), and the method based on measurement of the urine creatinine concentration (equation 2).

(1) electrolyte excretion $(\mu \mathrm{Eq} / \mathrm{min})=\mathrm{U}^{\mathrm{e}} \times \mathrm{D}$

(2) electrolyte excretion $(\mu \mathrm{Eq} / \mathrm{min})=\frac{\mathrm{U}^{\mathrm{e}}}{\mathrm{U}^{\text {cr }}} \times \mathrm{K}$

where $U^{e}\left(\mathrm{mEq} / \mathrm{l}\right.$ and $\mathrm{U}^{\mathrm{cr}}(\mu \mathrm{g} / \mathrm{ml})$ are the urine concentrations of an electrolyte and creatinine respectively, $\mathrm{D}(\mathrm{ml} / \mathrm{min})$ is urine volume and $K$ is a constant per $500 \mathrm{~kg}$ body weight.

Equation (2) is derived from equation (1) by division with $\mathrm{U}^{\mathrm{cr}}$,

of which

$$
\frac{\text { electrolyte excretion }}{\mathrm{U}^{\mathrm{cr}}}=\frac{\mathrm{U}^{\mathrm{e}} \times \mathrm{D}}{\mathrm{U}^{\mathrm{cr}}}
$$

(2a) electrolyte excretion $=\frac{\mathrm{U}^{\mathrm{e}}}{\mathrm{U}^{\mathrm{cr}}} \times\left(\mathrm{D} \times \mathrm{U}^{\mathrm{cr}}\right)$.

$\left(D \times U^{\text {cr }}\right)$ is the creatinine excretion which according to working hypotesis should be a constant (K) when correcting for body weight. This correction is indispensable as the creatinine production of the organism (Borsook et al. (2), Brody et al. (3)) and the glomerular filtration rate (Poulsen (9)) are directly proportional with the body weight. Control animals used for the estimation of $\mathrm{K}$ included 7 recently transported cows which were found free from proteinuria (Heller's test) and ketonuria (Legat's test made on a urine dilution 1 to 10). The animals showed normal appetite and apparently undisturbed general condition.

Methode of Analysis. The $\mathrm{Na}^{+}$and $\mathrm{K}^{+}$concentrations were examined by flame photometry (Beckman, model 41). The analysis of creatinine was carried out spectrophotometrically (Colman jr. spectrophotometer) as described by Poulsen (8). The measurement of urine volume was carried out after urine collection through a permanent bladder catheter (Rüsch Katheter No. 28, $77 \mathrm{cc}$ ) as described by Knudsen (7). The emptying of the bladder was provoked by air insufflation in the bladder lumen. During the first days after parturition the bladder was massaged via the vagina to facilitate emptying which appeared to be difficult to obtain post partum.

As it was difficult to weigh the immobile patients, the ordinary formulas for calculating bodyweight based on smallest chest circumference were used consistently, and thereby correction for foetal weight in pregnant animals was not necessary. 


\section{RESULTS}

Table 1 shows the calculated values for the constant $\mathrm{K}=$ $\mathrm{U}^{\text {cr }} \times \mathrm{D}$ per $500 \mathrm{~kg}$ body weight (about 9800 ).

T a ble 1. Calculation of the creatinine excretion $(\mu \mathrm{g} / \mathrm{min} / 500 \mathrm{~kg}$ body weight) in 7 normal, but recently transported cows.

\begin{tabular}{|c|c|c|c|c|c|}
\hline $\begin{array}{l}\text { Physiological } \\
\text { state }\end{array}$ & $\begin{array}{c}\text { Calculated } \\
\text { body weight } \\
\text { kg }\end{array}$ & $\begin{array}{l}\text { Length of } \\
\text { period } \\
\text { min. }\end{array}$ & $\begin{array}{c}\text { Urine } \\
\text { volume } \\
\text { (D) } \\
\mathrm{ml} / \mathrm{min} \text {. }\end{array}$ & $\begin{array}{c}\text { Concentrations } \\
\text { of creatinine } \\
\text { in urine } \\
([\mathrm{U} r r]) \\
\mu \mathrm{g} / \mathrm{ml}\end{array}$ & $\begin{array}{c}\text { Excretion } \\
\text { of creatinine } \\
(\mathrm{K}=\mathrm{D} \cdot[\mathrm{Ucr}]) \\
\mu \mathrm{g} / \mathrm{min} / \mathbf{5 0 0} \mathrm{kg} \\
\mathrm{b.} \mathbf{w}\end{array}$ \\
\hline Dioestrus & 632 & 36 & 5.3 & 2300 & 9650 \\
\hline ” & 543 & 114 & 5.1 & 2130 & 10000 \\
\hline , & 468 & 41 & 3.7 & 2500 & 9880 \\
\hline Oestrus & 634 & 35 & 7.3 & 1500 & 8640 \\
\hline Pregnant (10 weeks & 516 & 43 & 14.9 & 675 & 9740 \\
\hline , (5 months) & 526 & 32 & 3.0 & 3700 & 10550 \\
\hline$(7 \quad, \quad)$ & 386 & 39 & 3.0 & 2600 & 10100 \\
\hline
\end{tabular}

Transported animals were chosen for the control study since patients were always transported to the clinic and increased concentration of plasma creatinine had been observed after transport in most cows, irrespective of their state of health. To illustrate this, table 2 shows the creatinine concentrations in plasma

T a b l e 2. Creatinine concentrations $(\mu \mathrm{g} / \mathrm{ml})$ of plasmawater in cows under various conditions.

\begin{tabular}{cccc}
\hline Condition & $\begin{array}{c}\text { Number } \\
\text { of } \\
\text { of animals }\end{array}$ & $\begin{array}{c}\text { Creatinine } \\
\text { concentration } \\
\text { vations }\end{array}$ & $\begin{array}{c}\mu \mathrm{g} / \mathrm{ml} \\
\text { mean }\end{array}$ \\
\hline Normal cows, (Poulsen, 8) & 19 & 166 & $12.9 \pm 1.8$ \\
" , not transported & 7 & 7 & $12.5 \pm 1.1$ \\
" , recently transported & 7 & 7 & $16.9 \pm 2.7$ \\
Patients of Obstetric Dept. & 35 & 100 & $18.7 \pm 3.8$ \\
\hline
\end{tabular}

water of a group of normal recently transported animals, compared with the concentrations of a group of normal animals in accustomed surroundings. The difference between the two groups is significant $(\mathrm{P}<1 \%)$. The table further shows the creatinine concentrations in plasma water for the patients of the clinic during three months and for Poulsen's (8) normal material. 
The table seems to show an influence of plasma creatinine in transported animals, similar to the conditions in acutely ill animals. Based on Poulsen's normal material a correspondingly higher $\mathrm{K}$ (10.860) appears.

The factor 9800 (per $500 \mathrm{~kg}$ body weight) was therefore used on the patients, and the electrolyte excretion $(\mu \mathrm{Eq} / \mathrm{min})$ was calculated as

(2b) $\frac{\text { electrolyte conc. of urine }(\mathrm{mEq} / \mathrm{l})}{\text { creatinine conc. of urine }(\mu \mathrm{g} / \mathrm{ml})} \cdot 9800 \cdot \frac{\mathrm{kg} \text { body weight }}{500}$ the last fraction being the correction for body weight.

It appears from table 3 that among patients without noticeable fluid and electrolyte complications, the $\mathrm{Na}^{+}$and $\mathrm{K}^{+}$excretions found on the basis of creatinine ratios differ only 4-18\% from the excretions found by use of urine volume.

Table 4 shows that among patients with severe fluid and electrolyte complications the deviation was greater. With acute circulatory failure the deviation was large (136 and $300 \%)$, but apart from this complication more moderate deviation were found $(0-44 \%)$.

\section{DISCUSSION}

The method is based on assumption of constant creatinine excretion per $\mathrm{kg}$ body weight. Therefore, alterations in this excretion must be the essential uncertain factor of the method.

A constant creatinine excretion per $\mathrm{kg}$ body weight requires a constant creatinine production, independent of the protein metabolism and directly proportional to body weight. Normal cows fulfill these requirements almost ideally (Borsok et al. (2), Butcher \& Harris (4)). It also requires that excretion keep step with production. This is fulfilled because creatinine is excreted almost exclusively by glomerular filtration (Poulsen, 9), whereby the creatinine excretion (plasmawater concentration of creatinine $\left(\mathrm{P}^{\mathrm{cr}}\right) \cdot$ glomerular filtration rate $(\mathrm{GFR})$ ) will be equal to the creatinine production by an automatic adjustment of $\mathrm{P}^{\mathrm{cr}}$ depending on the actual GFR. This means that an interdependence between $\mathrm{P}^{\mathrm{cr}}$ and GFR should exist, and this was actually found by Poulsen (9).

In normal cows the creatinine excretion must thus be fairly constant, although not completely ideal. Differences in physical condition result in small variations of the creatinine production 


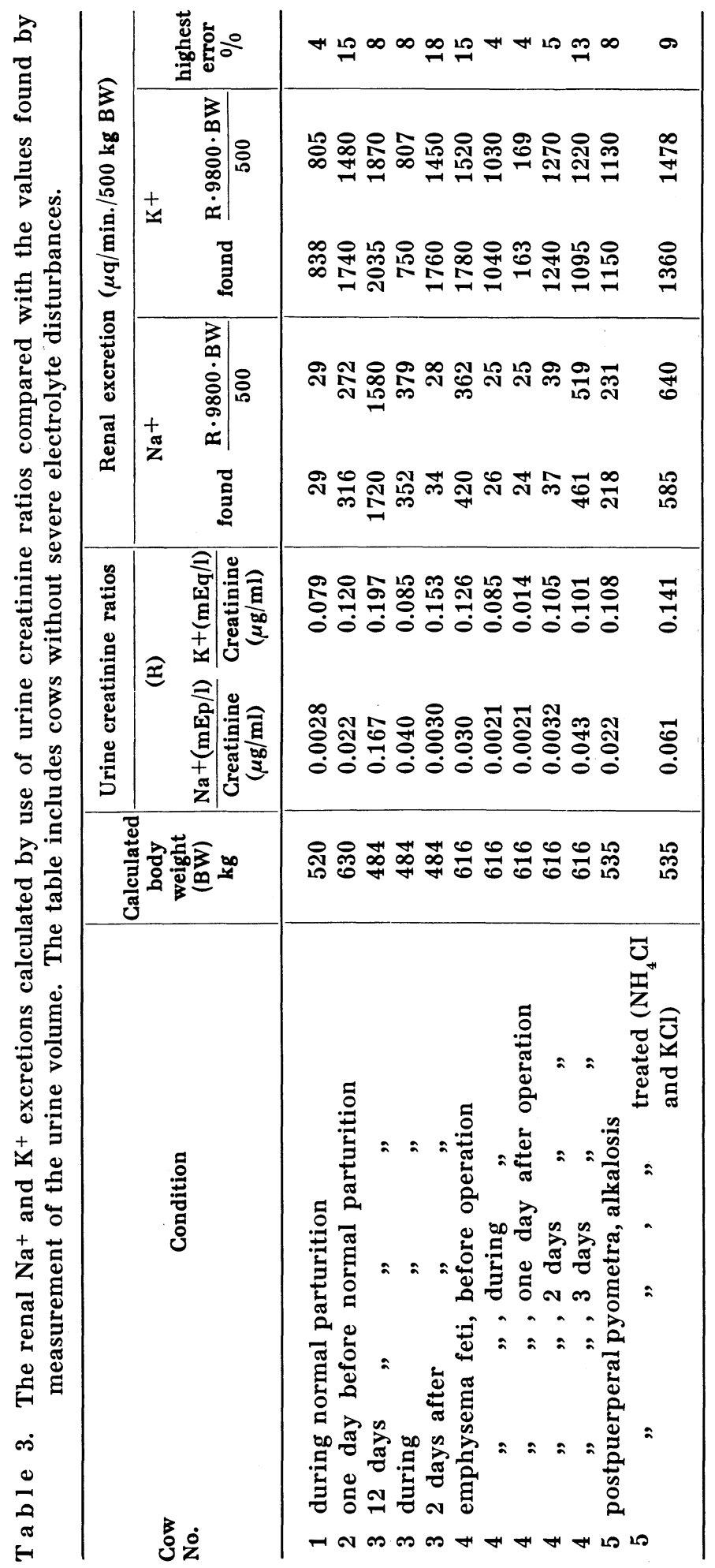




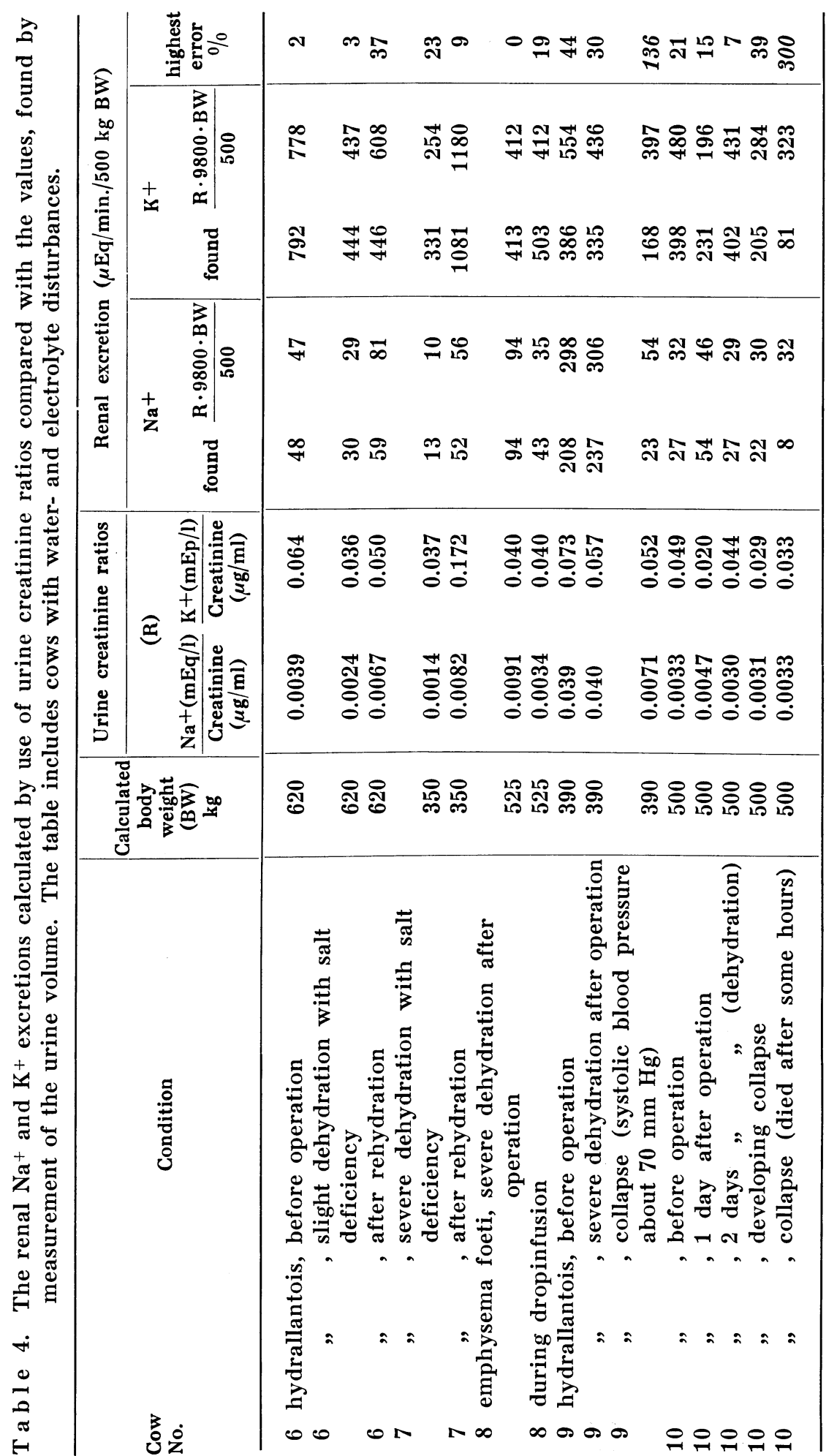


per $\mathrm{kg}$ body weight because the production is dependent on the muscle mass rather than the whole body. Also creatinine clearance differs somewhat from GFR. There seems to be some tubular secretion of endogenous creatinine (Taggart, 11). On the other hand some pseudocreatinine is reabsorbed in the nephrons (Blegen et al., 1), and the interdependence between these factors gives a $\mathrm{C} / \mathrm{I}$ (creatinine clearance/inulinclearance ratio) near 1 . In cattle Sellers et al. (10) found $\mathrm{C} / \mathrm{I}>1(1,06-1,25)$ and Poulsen (9) found $\mathrm{C} / \mathrm{I}=0,96 \pm 0,13(0,69-1,22)$. Therefore in patients without noticeable fluid and electrolyte disturbances, the error of $4-18 \%$ is hardly larger than might be expected in normal animals.

In severely diseased animals, however, acute and excessive alterations in GFR indicate that $\mathrm{P}^{\mathrm{cr}}$ cannot attain a new level quickly enough, and the excretion of creatinine will thus be temporarely altered. This presumably accounts for the greater error in the material of severely diseased animals. The low blood pressure in collapsed animals indicates a complete or partial inhibition of glomerular filtration, whereby a large error must be expected. Therefore in case of collapse and probably in developing uremia the method should not be used.

Apart from such cases the method seems to be sufficient for clinical use. In the clinic, it is of interest to know if the level of excretion is high or low. For example, high salt excretion in spite of salt loss dehydration indicates an endocrine or renal disease with a poor prognosis. Furthermore the general level of electrolyte excretion indicates the relative magnitude of individual electrolytes needed to avoid relapse during anorhexia. To these clinically purposes an estimation error less than $50 \%$ is believed acceptable.

Considering the error of 4-18\% in normal or slightly affected animals, the difference between $K$ in this material (9800) and $K$ based on Poulsen's normal material (10860) becomes so insignificant that $K=10000$ can be used as well. Equation (2) is hereby simplified,

(2c) electrolyte excretion $(\mu \mathrm{Eq} / \mathrm{min})=\frac{\mathrm{U}^{\mathrm{e}}}{\mathrm{U}^{\mathrm{cr}}} \cdot 10000$ (per $500 \mathrm{~kg}$ body weight)

or

electrolyte excretion $(\mathrm{mEq} / \mathrm{min})=\frac{\mathrm{U}^{\mathrm{c}}}{\mathrm{U}^{\mathrm{cr}}} \cdot 10$

(per $500 \mathrm{~kg}$ body weight), 
the electrolyte concentration being expressed as $\mathrm{mEq} / \mathrm{l}$ and the creatinine concentration as $\mu \mathrm{g} / \mathrm{ml}$.

The method can be extended so as to estimate the renal clearance and excretion percentage of the electrolyte if the plasma concentrations of the electrolyte $\left(\mathrm{P}^{\mathrm{e}}\right)$ and creatinine $\left(P^{\text {cr }}\right)$ are known. Using the excretion found according to the method described the following equations express clearance and excretion percentage:

(3) clearance $(\mathrm{ml} / \mathrm{min})=\frac{\text { excretion }(\mathrm{mEq} / \mathrm{min})}{\mathrm{P}^{\mathrm{e}}} \cdot 1000$

(the factor $\mathbf{1 0 0 0}$ is due to the fact that clearance is expressed in $m l$ whereas the electrolyte concentration is expressed per 1.)

(4) excretion percentage $=$ excretion $(\mathrm{mEq} / \mathrm{min}) \cdot \frac{\mathrm{P}^{\mathrm{cr}}(\mu \mathrm{g} / \mathrm{ml})}{\mathrm{P}^{\mathrm{e}}(\mathrm{mEq} / \mathrm{l})} \cdot 10$

\section{CONCLUSIONS}

1. Acute disease provokes an increase in plasma creatinine concentrations in cattle in various degrees. A similar but more stable increase in plasma creatinine concentration was found in normal cows which had been recently transported.

2. Apart from cases complicated by collapse and acute uremia, the substitution of urine creatinine concentration for the measurement of urine volume was found to be clinically satisfactory to estimate the renal electrolyte excretion in bovine patients with severe fluid and electrolyte complications.

\section{REFERENCES}

1) Blegen, E., H. N. Haugen \& K. Aas: Endogenous "Creatinine" Clearance. Scandinav. J. Clin. \& Lab. Invest. 1949, 1, 191200.

2) Borsook, H. \& J.W. Dubnoff: The Hydrolysis of Phosphocreatine and the Origen of Urinary Creatinine. J. Biol. Chem. 1947, $168,493-510$.

3) Brody, S., R. C. Proctor \& U. S. Ashworth: Growth and Development. Creatinine Nitrogen as a Function of Body Weight. Res. Bull. Mo. agric. Exp. Sta. 1934, 220, 17-18.

4) Butcher, J. E. \& L. E. Harris: Creatinine as an Index Material for Evaluating Ruminant Nutrition. J. Anim. Sci. 1957, 16, 1020.

5) De Groot, Th. \& J. H. Aarjes: On the Constancy of Creatinine Excretion in the Urine of the Dairy Cow. Brit. Vet. J. 1960, 116, 409-418.

6) Kemp, A.: Brit. Vet. Assoc. Conf. on Hypomagnesia, London 1960, p. 33. 
7) Knudsen, E.: Electrolyte Excretion in the Cow, as influenced by Variations in the Urine Flow. Acta vet. scand. 1960, 1, $305-323$.

8) Poulsen, E.: Renale clearanceunders $\varnothing$ gelser hos køer. Diss., K $\varnothing$ benhavn, 1956.

9) Poulsen, E.: Renal Clearance in the Cow. Yearbook Royal Vet.and Agricult. Coll., Copenhagen, 1957, pp. 97-126.

10) Sellers, A. F., W. R. Pritchard, A.F. Weber \& J. H. Sautter: Renal Function Studies on Normal Dairy Cattle and Those with Postparturient Albuminuria. Am. J. Vet. Res. 1958, 19, $580-584$.

11) Taggart, J. V.: Tubular Transport Mechanisms. Am. J. Med. 1950, $9,678-690$.

\section{SUMMARY}

Since measurement of urine volume can disturb the electrolyte excretion, and since such measurement is difficult to carry out on diseased cattle, a method to estimate the renal electrolyte excretion without measurement of urine volume has been tried and discussed.

Depending on a constant renal excretion of creatinine, the method allows substitution of measurement of urine cratinine concentration for measurement of urine volume. The largest source of error in the use of this method is alteration in the glomerular filtration rate, and the error of the method is therefore very high in case of cardiovascular collapse (136 and $300 \%$ was found here). The errors found were only 4-18\% in normal or slightly affected animals, and $0-44 \%$ in animals with severe fluid and electrolyte complications without collapse.

Apart from cases complicated by cardio-vascular collapse and acute uremia the method seems to be acceptable for clinical estimation of the renal electrolyte excretion.

\section{ZUSAMMENFASSUNG}

Bestimmung der renale Exkretion von $N a$ und $K$ aus Viehpatienten ohne Messung der Diurese.

Da die renale Elektrolytenexkretion durch gebräuchliche Diuresebestimmungsmethoden gestört werden kann und da diese an Rindern nur schwierig durchzuführen sind, wurde eine Methode zur Bestimmung der renalen Elektrolytenexkretion ohne Messung der Diurese untersucht und diskutiert.

Die Methode setzt eine konstante Kreatininexkretion voraus, wobei eine Bestimmung der Kreatininkonzentration im Harn die Messung der Diurese ersetzen kann. Ein wesentliches Unsicherheitsmoment der Methode sind akute Veränderungen in der Grösse der glomerulären Filtration, die wahrscheinlich für die grosse Unsicherheit verantwortlich ist, die man bei Tieren mit Kreislaufkollaps fand (Abweichungen 
von $136 \%$ und $300 \%$ von der konventionellen Methode). Bei nur leicht befallenen Tieren fand man Abweichungen von 4-18\% und selbst bei Patienten mit schweren Störungen des Flüssigkeits- und Elektrolytenstoffwechsels betrugen die Abweichungen nur 0-44\%.

Mit Ausnahme von Fällen mit Kollaps und akuter Urämie wurde die Methode daher bei der klinischen Bestimmung der renalen Elektrolytenexkretion für brauchbar befunden.

\section{SAMMENDRAG}

Renal Na-og K-ekskretion hos kvægpatienter bestemt uden måling af diuresen.

Da den renale elektrolytekskretion kan forstyrres af almindelige diuresemålingsmetoder, og da sådanne er vanskelige at udføre på kvægpatienter, er en metode til bestemmelse af den renale elektrolytekskretion uden diuresemåling blevet unders $\emptyset \mathrm{gt}$ og diskuteret. Metoden forudsætter en konstant kreatininekskretion, hvorved en bestemmelse af urinens kreatininkoncentration kan erstatte måling af diuresens st $\not$ rrelse. Metodens væsentligste usikkerhedsmoment er akutte ændringer i den glomerulære filtrations st $\varnothing$ rrelse, hvilket antagelig er ansvarlig for den store usikkerhed, som fandtes hos dyr med kredsl $\varnothing$ bskollaps (afvigelser på 136 og $300 \%$ fra den konventionelle metode). For let påvirkede dyr fandtes afvigelser på 4-18\%, og selv for patienter med svære væske- og elektrolytforstyrrelser var afvigelserne kun $0-44 \%$.

Bortset fra tilfælde med kollaps og akut uræmi skønnes metoden derfor anvendelig ved klinisk bestemmelse af den renale elektrolytekskretion.

(Received August 13, 1963). 